
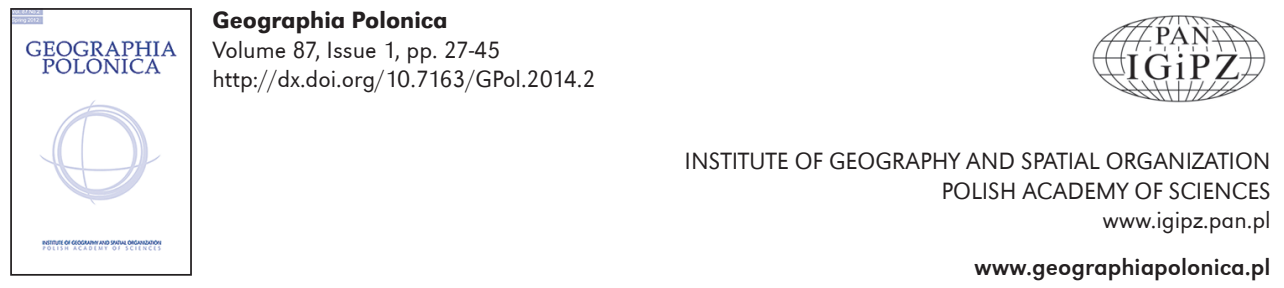

\title{
THE CONTEMPORARY SITUATION OF THE POLISH MINORITY IN LITHUANIA AND THE LITHUANIAN MINORITY IN POLAND FROM THE INSTITUTIONAL PERSPECTIVE
}

\author{
Marek Barwiński • Katarzyna Leśniewska \\ University of Łódź \\ Faculty of Geographical Sciences \\ Kopcińskiego 31, 90-142 Łódź: Poland \\ e-mails: marbar@geo.uni.lodz.pl • katerina.lesniewska@gmail.com
}

\begin{abstract}
Contemporary Polish-Lithuanian relations are heavily burdened by radically different assessments of the situations of the national minorities in the two countries, i.e. Poles in Lithuania and Lithuanians in Poland. However, assessments are fraught with difficulties reflecting a complicated history and the different potentials of the two minorities, and also warped by a great many stereotypes. The main aim of this paper is to compare the situations of the Polish minority in Lithuania and the Lithuanian minority in Poland by reference to criteria that are objective (demographic potential, legal status, organisational activity, education) or subjective (the opinions of leaders of national organisations), as well as to attempt to determine how the different situations of the two minorities affects their relations with the authorities, the majority and the foreign homeland.
\end{abstract}

\section{Key words}

ethnic geography $\cdot$ national minorities $\bullet$ interstate relations - Polish minority - Lithuanian minority - Polish-Lithuanian relations

\section{Introduction}

In the present era the ethnic compositions of many countries is rather mixed. The territories of countries both large and small are inhabited by many ethnic groups including national minorities that are often very different from one another. They have appeared inter alia as a result of natural movements of population and changes in borders.

Many changes in political affiliation during the last few centuries have given rise to a situation whereby East European countries are inhabited by many minorities. National minorities are today quite important parts of various societies, but they also have different 
functional possibilities. In many countries minorities may be of differing legal status, with attendant impacts on their situations (Eberhardt 1996, 1997; Żołędowski 2003; Janusz 2011).

Over the past several decades, Polish-Lithuanian relations have been through several very different stages - from overt hostility, through 'socialist friendship', early 1990s mistrust, cooperation and strategic partnership within NATO and the EU at the beginning of the 21st century, to a clear cooling of mutual relations again recently. How ties will look in the future depends largely on the situations of the Polish and Lithuanian minorities in the two countries.

According to the 2011 census, Poles are the largest national minority in Lithuania (accounting for some 200,000 people out of 3 million), and are represented by many organisations. In contrast, the Lithuanian minority in Poland is not so large (only about 8000 people among 38 million), though these people also have their own institutions.

This paper offers a comparison of the demographic, political and legal activity and education of the two national minorities, as well as a comparison of the contemporary situations of the two nations in the opinions of the leaders of Polish organisations in Lithuania and Lithuanian organisations in Poland. It is based on empirical research, and provides conclusions asserting whether and how the different legal, demographic and institutional situations affect behaviour as regards the Lithuanian and Polish national identities and relations with the inhabited country and nation.

\section{Poles in Lithuania at the beginning of the 21st century}

The first census of the 21st century in Lithuania was carried out in 2001. According to the data it generated, the number of Poles was about 235,000 - out of a total population of nearly 3.5 million. The Polish population accounted for $6.74 \%$ of the country's population, and thus constituted the largest national minority in Lithuania (Eberhardt 2009). Almost half of these lived in the capital city of Lithuania - Vilnius. Moreover, the Polish population concentrated in the two district municipalities of Vilnius and Šalčininkai (Fig. 1).

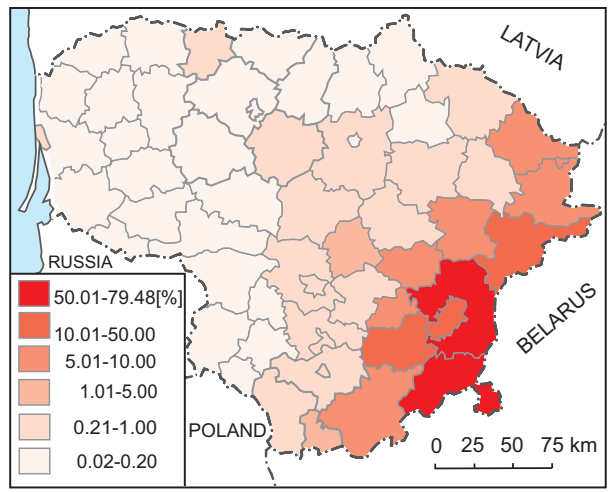

Figure 1. Percentage of populations in different municipalities of Lithuania declaring Polish nationality in the 2001 census

Source: based on http://db.stat.gov.lt.

The last census in Lithuania took place in 2011 and according to the data from it, Poles were about 200 thousands out of about 3 million population. The comparison between the two censuses thus shows a decline of almost 15\% in Lithuania's Polish population. In 2011, 79\% of Poles declared Polish to be their mother tongue (a decrease of $1 \%$ compared with 2001).

\section{Lithuanians in Poland at the beginning of the 21st century}

The distribution of Lithuanians on Polish territory has not changed significantly since the end of World War II. This is an indigenous minority with a strong territorial concentration, mostly living in a regional ethnic homeland called 'Little Lithuania', with its capital city in Puńsk. In the census of 2002, Lithuanian nationality was declared by 5846 people, 
of whom $90 \%$ lived in the Polish-Lithuanian borderland. The largest group of people within the Lithuanian minority was in Puńsk, where almost $60 \%$ of Polish Lithuanians (3312 people) resided, this also representing $75 \%$ of the population overall (Fig. 2). Puńsk was one of only five gminas in Poland, in which, according to the 2002 census, the Polish population was in a minority.
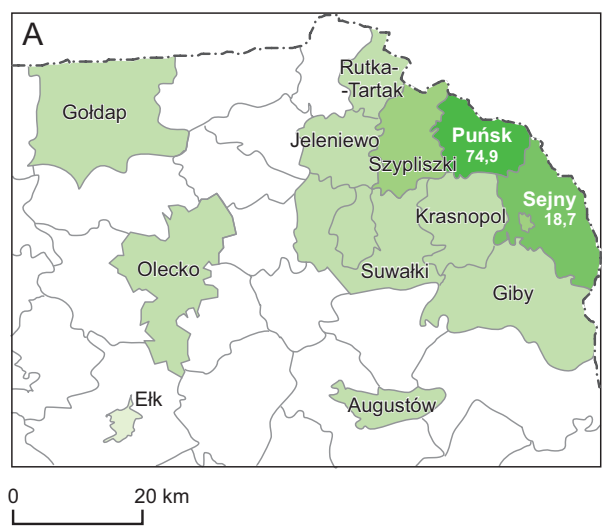

The percentage of people declaring Lithuanian nationality $\begin{array}{llllll}0.005 & 0.1 & 1.0 & 10.0 & 20.0 & 74.9\end{array}$

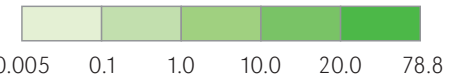

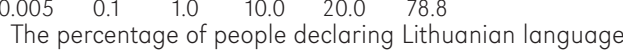

identity. The possibility of dual national identity benefited 3032 people identified with the Lithuanian nation, nearly $40 \%$ of the total. The vast majority of these were people who declared alongside the Lithuanian a Polish nationality, often even in first place. However, for 4830 people (over 60\%) Lithuanian identity was the only national identity. Still the most populous of the Lithuanian minor-

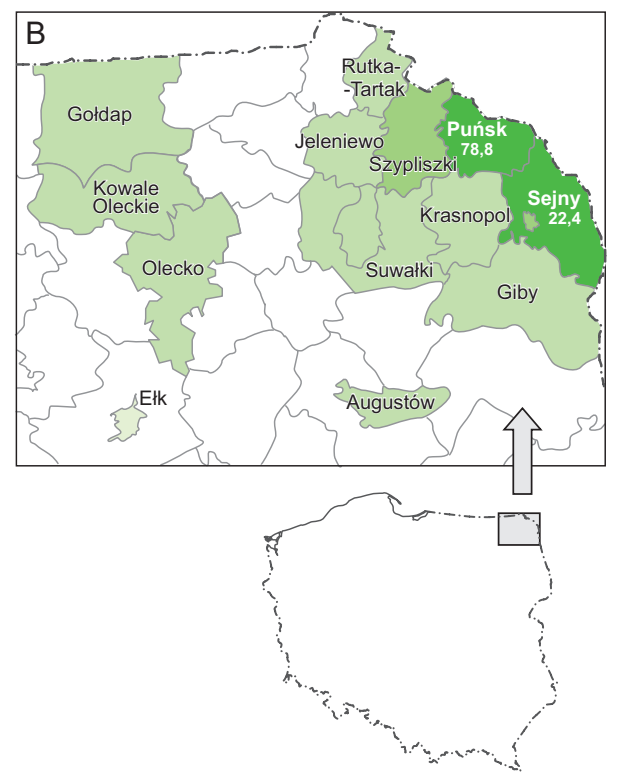

Figure 2. The percentage of people declaring Lithuanian ethnicity (A) and the use of the Lithuanian language (B) in the Polish-Lithuanian borderland (by gmina), based on the 2002 census

Source: based on data from the Central Statistical Office.

The next census (of 2011) was carried out using methodology entirely different from that employed in 2002. The substantial differences in the conduct of the two censuses, especially in the formulation of questions about ethnicity, nationality determination and the obtainment of information and evaluation of results, hinder direct comparisons and limit the educational value of any results obtained.

In the course of the 2011 census, Lithuanian nationality was declared by a total of 7863 people, including 5599 (71\%) who reported it in first place, and 2264 who treated it as a second declaration of ity concentrations were peripherally located in the Polish-Lithuanian borderland, with Lithuanians being among the smaller minorities in today's Poland.

\section{Legal conditioning of the situation faced by Poles in Lithuania}

The main legal act in Lithuania which regulates the rights of national minorities there is the Constitution of the Republic of Lithuania adopted in 1992. Article 37 refers to citizens belonging to ethnic communities enjoying the right to have their language, traditions and culture respected. Moreover, representatives 
of national communities deal with issues concerning national culture, philanthropy, education and mutual support (Art. 45). In addition, ethnic communities are supported by the state. Article 29 of the Constitution prohibits restrictions on human rights, and also preferential treatment on the grounds of gender, race, nationality, language, origin or social status. In addition, Article 25 includes among criminal acts any national, racial and religious hatred, to this extent limiting freedom of expression and the dissemination of information (Łodziński 1998; Zakrzewski 2000; Białek 2008).

As Białek (2008) noted, the provisions of the Lithuanian Constitution are rather laconic, in particular when it comes to statements such as: "the state supports national communities". Kuzborska (2012) further observes that the said Constitution does not guarantee any rights to the national minorities present in Lithuania solely on the basis of their existence, instead limiting itself to non-discrimination, with no special status afforded.

The act regulating the rights of national minorities in Lithuania until recently was the National Minorities Act adopted on 23 November 1989. This guaranteed the fundamental rights of national minorities, emphasizing in the preamble that the state guaranteed equal rights and political, economic and social freedoms for all citizens, independently of their nationality. Furthermore, it acknowledged national identity and cultural continuity, and also encouraged manifestations of national awareness (Białek 2008). In addition, the preamble emphasized that inhabitants of the Lithuanian Republic, irrespective of nationality, should abide by the Constitution and protect the state sovereignty and territorial integrity of Lithuania (Łodziński 1998).

However, one of the major weaknesses of the Lithuanian Act on national minorities concerned its failure to define that concept in the first place, or to offer guidelines as to who might be embraced by it. Article 1 of the Act introducing the whole framework provides that Lithuania is guided by principles regarding the equality of nations and as such guarantees the representatives of national minorities living on its territory their free development, with respect extended to all nationalities and languages. There was also a prohibition on any discrimination based on race or national background (Łodziński 1998; Białek 2008).

Article 2 of the Act on National Minorities further provided for a post-1989 guarantee that representatives of minorities would enjoy the right to:

- culture and education in the mother tongue in teaching and in print,

- freedom of religious belief,

- association within national and cultural organisations,

- positions in organs of state authority (Białek 2008).

The Act also allowed for bilingualism in offices and for the use of information boards in languages of given minorities within the areas inhabited by them (Arts. 4 and 5). In addition, Article 8 stipulated that every citizen of Lithuania was free to determine his/ her ethnic identity on the basis of the nationality of both parents, or of one or the other (Łodziński 1998).

Unfortunately, the Act on National Minorities in Lithuania ceased to have application from 1st January 2010 (Kuzborska 2012), and this lapse gave rise to a situation in which Lithuania lacks even a single piece of legislation regulating the plethora of matters relating to national minorities.

Members of the Electoral Action of Poles in Lithuania have sought unsuccessfully for years now to have new law on national minorities adopted. In that light, Lithuania's 2000 ratification of the Council of Europe's Framework Convention for the Protection of National Minorities is interesting, though the Convention has tended to be dismissed as nothing more than a political document by the leaders of Polish organisations.

While Lithuania's declaration of independence was proclaimed on 11 March 1990, it was only in August 1990 that most Western countries recognized that independence. 
Diplomatic relations between Poland and Lithuania resumed on 5th September 1991, in line with the content of letters of intent exchanged prior to that. As a result of closer cooperation between the two countries, a Polish-Lithuanian Declaration on friendly relations and neighbourly cooperation was signed at Vilnius on January 13 1992. This agreement went beyond respect for national sovereignty and resignation from territorial claims to refer also to matters of national minorities. Indeed, it was confirmed at this point that the two countries would apply European standards where the protection of minority rights was concerned. Although both sides thus declared a willingness to put in place favourable conditions for minorities to meet their needs as regards language, education, culture and religion, nothing concrete to enforce these goals ever entered into force (Bobryk 2006; Wołłejko 2011; Kuzborska 2012; Mole 2012).

Another act regulating matters of the Polish minority in Lithuania was the 21st February 1992 Agreement signed between the Ministry of National Education of Poland and the Ministry of Culture and Education of the Republic of Lithuania - in the field of education and higher education. This Agreement focused mainly on the development of cooperation between the two countries in the field of education at all levels. It aspired to there being extensive and direct cooperation between schools and educational establishments in the two countries, the parties agreeing to create a bilateral group of experts that would cooperate over the preparation of textbooks. At the same time a willingness to cooperate in the field of the education and training of teachers was expressed, while the two countries also agreed to address the issues of Baltic and Lithuanian studies in Poland, as well as Polish in Lithuania (Leśniewska 2009).

The culmination of the process by which good neighbourly relations were strengthened entailed the Treaty on Friendly Relations and Good Neighbourly Cooperation of the Republic of Lithuania and Republic of Poland, signed on 26 April 1994, which included provisions as regards the protection of the rights of national minorities. Specifically, Treaty Articles 13-17 inclusive are devoted to matters of the protection of the rights of the Polish minority in Lithuania and the Lithuanian minority in Poland. Furthermore, all provisions were drafted in such a way as to comply with the applicable international standards (Łodziński 1998; Brodowski 2000). The Treaty was signed into law for a period of 15 years, but included a clause allowing for automatic renewal for successive 5-year periods (Kuzborska 2012).

Article 13 of the Treaty defined the precise subject of the protection as "persons, having Polish citizenship, who are of Lithuanian descent or consider themselves as belonging to the Lithuanian nation, culture, and traditions and regard Lithuanian as their mother tongue, as well as persons, having Lithuanian citizenship, who are of Polish descent or consider themselves as belonging to the Polish nation, culture, and traditions and regard Polish as their mother tongue". Article 14 in turn clarifies the rights to which representatives of minorities are entitled, including:

- free use of the minority language and access to information in that language;

- learning the language of the national minority, and learning in this language;

- in accordance with national law, the establishment and maintenance of own institutions, organisations or associations, in particular cultural, religious and educational institutions, including schools at all levels;

- profession and practice of their own religion;

- participation in public life, either directly or through freely chosen representatives at the state and local level (Łodziński 1998; Wołłejko 2011).

In addition, both parties agreed to prepare a separate agreement laying down detailed regulations as regards the spelling of names. Article 15 refers to approval regarding the languages of national minorities, in particular in the administrative units in which a large part of the population belongs to the minority. 
In addition, both sides agree to stop activities aimed at the assimilation of national minorities against their will. At the same time places and culture connected with historical events and achievements of minorities are to be brought under special protection (Łodziński 1998; Wołłejko 2011; Kuzborska 2012).

The signing of the Treaty did not mean to provide political autonomy for the Polish minority, as was lobbied for by some of the Polish organisations in Lithuania. Moreover, while in Poland protection has become standard, in Lithuania it is still the cause of many conflicts between representatives of the Polish minority and the state authorities (Łodziński 1998; Barwiński 2013b).

As noted by Barwiński (2013b), the most important problem facing Polish-Lithuanian relations is the treatment of Poles in Lithuania, where the authorities continue to implement many provisions limiting rights significantly (in particular the right to use the Polish language and to access and organise Polish education). Still-unresolved issues concern the spelling of Polish names in documents, and the use of signs with the names of streets and places in Polish in areas densely inhabited by Poles (Leśniewska 2013).

In addition, many leaders of Polish organisations in Lithuania are of the view that the Polish minority is also discriminated against by a new law on education coming into force in 2011. One of the most harmful provisions therein concerns the unification of Lithuanian-language matriculation exams in minority schools from 2013 onwards. The fact that the transition period allowing curricula to be adapted to requirements of the new law was of just two years' duration inclined Poles to accuse the Lithuanian side of taking action against national minorities. Initially, Poles demanded mild rating of the exams in schools for national minorities, as well as an extension of the said transition period. One idea was that the new exam rules would only be introduced in the case of students just embarking upon their education. However, the Lithuanian side did not give way in the face of these demands, and nor were there any changes in the wake of the many mass demonstrations staged in Vilnius following the adoption of the controversial act.

In June 2013, all high-school students in Lithuania were required to pass the unified Lithuanian-language exam. The curriculum in schools was likewise changed in 2011, one impact of this being that students attending national-minority schools who took exams in 2013 did so having had some 700 hours fewer Lithuanian-language lessons than their counterparts from Lithuanian schools. As of 2011, high school students began taking the Lithuanian language exam in terms of it being their native language, while it was deemed to be the state language in the case of students from minority schools.

It is worth mentioning that the activity of Electoral Action of Poles in Lithuania ensured some accommodation of minority students by the Lithuanian Minister of Education, notably a reduction of the word limit for essays to at least 400, not 500. However, the Supreme Administrative Court ruled that the concession made by the Ministry for minority students at the matriculation exams is contrary to the constitutional principle of equality set out in Article 29 of the Constitution (Lisiewicz 2013).

Considerable controversy between Poles and Lithuanians arose following the Polish Government's adoption of the Act on the Polish Charter Act in September 2007. The Polish Charter is a document confirming 'belonging to the Polish nation', but not granting Polish citizenship.

The rights extending to holders of a Polish Cards include:

- an exemption from the obligation to have a work permit,

- an entitlement to study, do a PhD and participate in other forms of education,

- an entitlement to use healthcare services,

- discounts on means of public transport,

- free admission to national museums (Leśniewska 2009).

Lithuanian law allows for dual citizenship, but only for ethnic Lithuanians. This again means that representatives of the Polish 
minority are discriminated against, in that they have been excluded from this privilege (Trusewicz 2005). In 2008, two representatives of AWPL ${ }^{1}$ - Michał Mackiewicz and Waldemar Tomaszewski - were elected to the Lithuanian parliament. Both are holders of the Polish Charter, leading the Lithuanian side to recognise the existence of documents and legal obligations vis-à-vis another state, and hence an obstacle to these persons exercising their parliamentary functions in Lithuania.

\section{Legal conditioning of the situation of Lithuanians in Poland}

The rights of national minorities are guaranteed by the Constitution of the Republic of Poland passed in 19972, and by numerous other acts of law adopted since 1989, not least: the Freedom of Conscience and Religion Act (1989), the Association Law Act (1989), the Assemblies Law Act (1990), the Education Act (1990), the Political Parties Act (1997) and the Sejm and Senate Voting System Act (2001). A number of bilateral treaties with all of the neighboring countries concluded by Poland constituted further significant elements in the protection of the rights of minorities, especially at the beginning of the 1990s. Moreover, in line with Poland's membership of the Council of Europe, the Polish government signed (and a few years later Parliament ratified) the Convention for the Protection of Human Rights and Fundamental Freedoms (1993), the Framework Convention for the Protection of National Minorities (2000) and the European Charter for Regional or Minority Languages (2009).

However, the most important legal document for the national and ethnic minorities in Poland is the Act of 6 January 2005

1 Electoral Action of Poles in Lithuania (Lithuanian: Lietuvos lenku rinkimu akcija or LLRA; Polish: Akcja Wyborcza Polaków na Litwie or AWPL) - a political party in Lithuania represents the Polish minority.

2 Article 35 is fully devoted to this issue. The Constitution also includes other articles directly or indirectly dealing with the protection of rights of national minorities (Arts. 13, 25, 27, 32, 53, 57, 58, 60; Dziennik Urzędowy 1997). on National and Ethnic Minorities and on the Regional Languages (Dziennik Ustaw 2005), wherein the notion of a minority is defined and a detailed list of rights and duties of representatives of national minorities in a democratic Poland supplied. The Act in question was passed - after numerous disputes - as late as at the beginning of 2005, notwithstanding the fact that deliberations over it had first started in 1989. The main objections to the Act concerned the costs of implementation, the possibility of ethnic conflicts breaking out, the extensive nature of the rights granted to the languages spoken by minorities, and especially the bilingual naming of towns, plus the lack of application of the reciprocity principle given that the situation of the Polish minority in other countries was not being taken account of in an equivalent way (Barwiński 2010; Janusz 2011).

The Act affords national and ethnic minorities the opportunity to maintain their own cultural and linguistic identity, as well as proscribing both discrimination and assimilation. For some of the minorities (inter alia the Lithuanian), a particularly significant provision of the Act concerns the right to have names put in official documents in accordance with the spelling rules of the given minority language. Furthermore, the Act assures the possibility of a minority language being used as an 'auxiliary language' at municipal offices. A condition for this provision to be implemented is that a minimum of $20 \%$ of all residents in a given gmina declared an affiliation with a national minority at the time of the national census, and that a relevant application by a given Gmina Council has been submitted in line with that fact. In the light of the 2002 Census, the possibility referred to in fact arises in 51 gminas. However, as of January 2013, applications seeking the right to exercise the right had only been received from 31 gminas. Among these, the gmina of Puńsk has Lithuanian as its auxiliary language.

Moreover, the Act offers the possibility of additional 'traditional' names being used for towns, villages and other physiographical 
objects in the minority language alongside the names in Polish. Bilingual names may be introduced in response to an application from a gmina council in any town or village, even one inhabited by just a few members of national or ethnic minorities, the only condition being that 'consultations' have been run with residents. The consultation is usually a residents' vote (a referendum) with no minimum voter turnout requirement. It is mainly in line with the very liberal nature of these regulations concerning bilingual names that such names are noticeably becoming more and more popular. As many as 798 bilingual names had been introduced in Poland as of January 2013. Two communities are definite leaders where the introduction of bilingual names is concerned. These are Kashubians (397 names in the Kashubian language) and Germans (335 names in German). Bilingual names of towns and villages in Polish and Kashubian or German constitute $92 \%$ of all the names of this kind in Poland. In the Lithuanian language there are 30 names of villages applied within the gmina of Puńsk.

Bilingual names have been provoking disputes and stirring up emotions in Poland since the early 1990s. This was mainly true of Polish-German names in the Opole region, as well as - only recently - a Lemko name for Bielanka village, which is the first name in contemporary Poland to be spelt in Cyrillic. In addition to the various types of verbal protests and conflicts among local communities, there have also been instances of bilingual names being painted over, or destroyed in some other way. In August 2011, in the course of a single night, some 28 Polish-Lithuanian signs in the gmina of Puńsk were painted over. However, from the point of view of the minority, these represent one of the most important ways of manifesting and maintaining identity, as well as serving as a kind of confirmation of the multinational history of given regions.

The improved legal situation of ethnic minorities in Poland relates inter alia to Poland's 2004 accession to the EU - an event recognised and appreciated by the leaders of national organisations, who stress that the main consequences of Poland's membership of the EU for the communities they represent do not lie in the potential financial benefits, but rather in improved legal standards where the protection of ethnic minorities is concerned. This is a universally held opinion, very strongly rooted in the consciousness of the leaders of national organisations, even though it is not exactly applicable to EU legislation (Barwiński 2013b). The EU law does not include any regulations concerning the rights of ethnic minorities, even though the EU requires its Member States to respect standards set out in international law as regards minorities. The EU legislation only protects the so called lessused languages (which may in practice mean some of those used by ethnic minorities), but it does not introduce a common national policy. As a result, each country regulates the legal issues of ethnic minorities on its own. However, the EU legislation clearly prohibits discrimination on grounds of gender, race, religion, ethnic and social origin and the colour of one's skin, yet no EU documents make direct mention of ethnic minorities. There are also no special programmes through which minorities may gain financial support. The latter can do no more than apply for financing for their projects as part of more wideranging EU initiatives (involving the Structural and Cohesion Funds). The legislation of the Council of Europe concerning the legal protection of ethnic minorities is much more extensive (Budyta-Budzyńska 2010; Janusz 2011).

It is frequent for solutions already included in Polish law and dealing with the many issues relating to non-Polish nationalities to anticipate well in advance the recommendations as regards the rights of national and ethnic minorities arrived at in international conventions. At present, the main problem seems to be a frequent lack of reciprocity in legal regulations concerning national minorities in Poland as opposed to the Polish minority in neighboring countries. This is especially the case in Lithuania. In legal terms, the situation 
of the Lithuanian minority in Poland is now much better than that of the Polish minority in Lithuania.

\section{The institutional life of Poles in Lithuania in the 21st century}

Members of the Polish national minority in Lithuania are organised into several associations, groups and organisations engaging in a wide range of activities. There are thus many large organisations with thousands of members, as well as small associations whose limited membership reflects the need of specific people to take specific action (Fig. 3). The results of all of this activity include Polish schools, social organisations, theatres and several folk groups.

The largest and most important Polish organisation in Lithuania is the Union of Poles in Lithuania (Związek Polaków na Litwie - ZPL), established in 1989. The main purpose of this organisation was to take care of a Polish national revival in the region and to defend the interests of the Polish minority (Trusewicz 2005). The organisation grew to nearly 15,000 members (Jackiewicz 2007).

The main objectives of the Union of Poles in Lithuania are: to preserve the national identity of the Polish minority in Lithuania, to ensure the free development of Polish culture and to ensure decent living conditions for the population in the Vilnius region (Masłowski 2005).

In its nearly 25-year history, ZPL has greatly influenced not only the development of Polish culture, but also the spread of the Polish language, with Registrar's Offices starting to conduct weddings in Polish, for example. The Union's activities are mainly focused on answering the current needs of the Polish community in Lithuania. With ZPL, an amateur folk movement developed, many Polish clubs and associations opened, and Polish libraries were created. The Union of Poles in Lithuania's main focus is on the free participation of minorities in the political and economic life of the Republic of Lithuania (Bobryk 2006; Leśniewska 2013).
It is worth mentioning that the impulse underpinning the formation of many Polish organisations has involved the political changes taking place in Lithuania, as a consequence of the disintegration of the USSR. The intensity and range of activities of most organisations is dependent on financial support from Poland. Furthermore, as many Polish organisations were founded more than 20 years ago now, there is a need for a generational handover of management responsibilities.

1989 saw the establishment of the Scientists' Association of Poles in Lithuania (Stowarzyszenie Naukowców Polaków Litwy - SNPL). Today this organisation has 62 members, including 8 Professors. The Association's activities mainly entail the organising of conferences, lectures and discussions concerning the situation of national minorities in Lithuania. SNPL also carries out research focusing on the problems the Polish minority in Lithuania faces. The Association helps talented young people to prepare for education and research. In addition, it works with organisations supporting research activity. SNPL only admits academics who are citizens of the Republic of Lithuania, and who are active in the sciences or the arts. Prospective members must submit a list of their publications, and their application is subjected to a confidential voting process (Masłowski 2005; Leśniewska 2013).

In 1994, the Lithuanian Parliament adopted a law on organisations in society, which ordered them to specify precisely the nature of their activity. This led to a situation, in which an organisation is not permitted to serve both social and political functions, with representatives forfeiting the right to participate in elections. This forced the ZPL to become a social organisation. However, a new political party emerged from it, namely Electoral Action of Poles in Lithuania (Akcja Wyborcza Polaków na Litwie - AWPL). The party has more than 1100 members currently (Godek 2005; Masłowski 2005; Trusewicz 2005; Bobryk 2006), its statute setting out basic objectives that include: consolidation of democracy in Lithuania, defence 


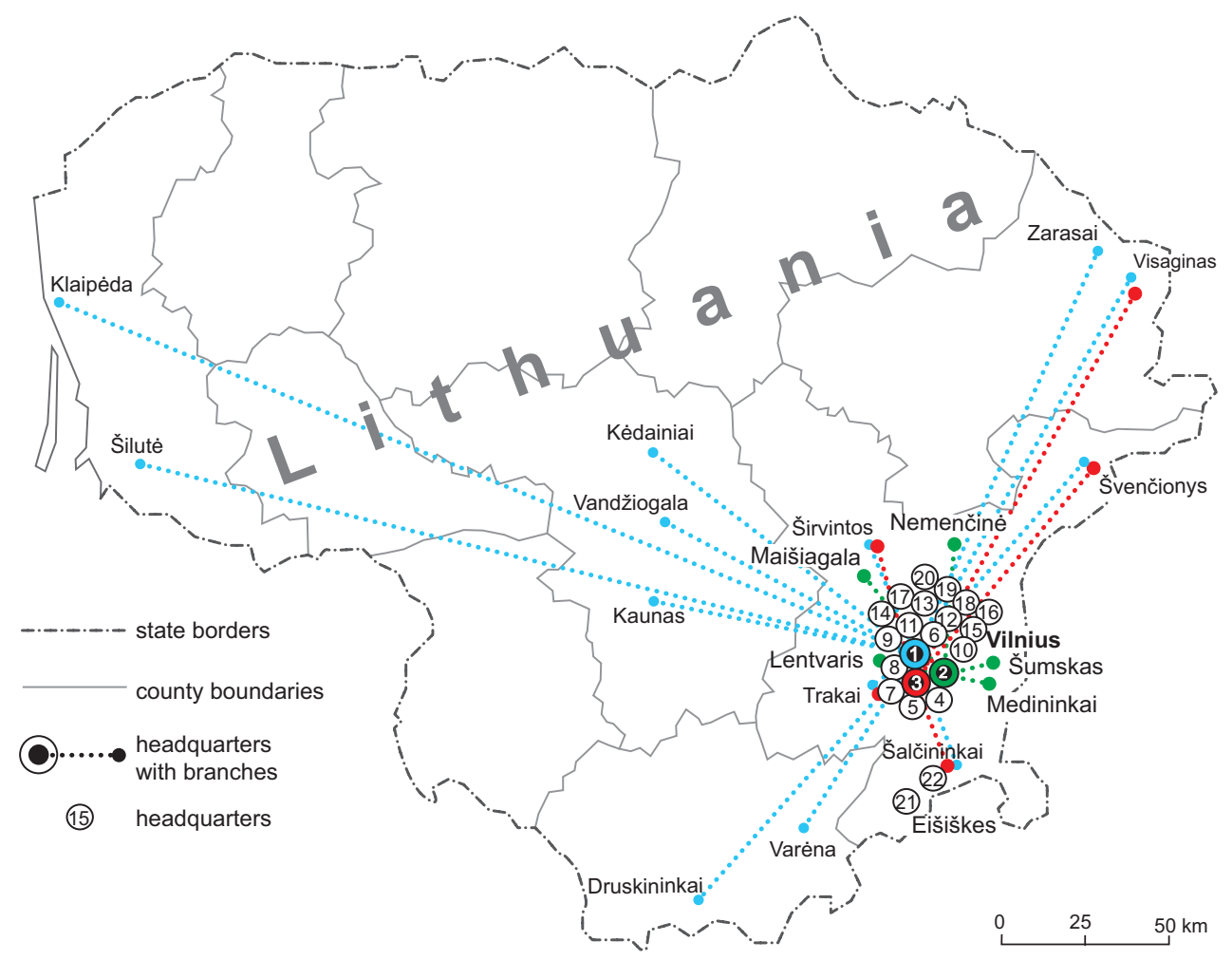

Figure 3. Main Polish socio-political organisations in Lithuania in 2012

Organisations: 1 - Union of Poles in Lithuania, 2 - Polish Scouting and Guiding Association in Lithuania, 3 - Electoral Action of Poles in Lithuania, 4 - Association of Polish Medics in Lithuania, 5 - Polish Section of the Vilnius Community of Prisoners and Exiles in Lithuania, 6 - Scientists' Association of Poles in Lithuania, 7 - Polish Educational Society, 8 - Catholic Association of Poles in Lithuania, 9 - Vilnius Club of 'Vagabonds', 10 - 'Polonia' Sports Association of Poles in Lithuania, 11 - Vilnius Guides' Club, 12 - Philanthropic Polish Combatants Association, 13 - Association of Polish Engineers and Technicians in Lithuania, 14 - House of Polish Culture, 15 - Polish Students' Club, 16 - Lithuanian Associations of Polish Women, 17 - 'Litpolinva' Polish Association of the Disabled, 18 - Association of Building-Sanitary Engineers and Technicians in Vilnius, 19 - Polish Lawyers' Association in Lithuania, 20 - Polish Catechetical Centre, 21 - Polish House, 22 - 'Sokół' Gymnastic Association

Source: based on: www.wilnoteka.lt, www.salcininkai.lt, www.vilniaus-r.lt, www.portalszkolny.org, www. zpl.lt, www.polonia.lv, www.polskidom.lt.

of human rights, ensuring social justice and economic prosperity and ensuring cultural development for representatives of all the nations in Lithuania. AWPL pursues these objectives through participation in elections at all levels, the defence of interests by legal and political means, cooperation with other parties and efforts to improve their programs (Leśniewska 2013).
AWPL's program is divided into nine areas, the priorities being the reform of local government with a view to power at this level being enhanced; the economic development of the country, especially the Vilnius Region; and the ensuring of equal rights for all citizens irrespective of nationality. Since its formation, AWPL has repeatedly defended the interests of the Polish minority in Lithuania. 
Gradually it has also been implementing its election promises, and has contributed to the development of technical infrastructure and equipment in Polish schools (Godek 2005).

The most important promises concerning the national minorities in Lithuania are: that education of national minorities in schools should be promoted, the European Charter for Regional or Minority Languages ratified by Lithuania, and the Citizenship Act amended (to ensure that representatives of national minorities can possess dual citizenship). A further goal for administrative units in which national minorities account for more than $10 \%$ of the population is that the language of that minority be introduced in offices (Leśniewska 2013).

The most important Polish cultural organisation in Vilnius is the so-called House of Polish Culture (Dom Kultury Polskiej - DKP), which was created in 2001 at the initiative of ZPL and the Polish Community Association. This institution organises concerts, theatre performances, competitions, exhibitions of contemporary art, Polish film screenings and other educational and promotional events (Jackiewicz 2007). DKP works with many (currently around 30 ) community organisations by letting them use premises as offices. The priorities of DKP in Vilnius include 'cultural education', as defined broadly, through the promotion of Polish art and literature among inhabitants of the city. DKP also supports all local art movements (Leśniewska 2013).

Polish education in Lithuania has a very important position and has played a significant role in preserving Polish national identity (Osipowicz 2001; Żołędowski 2003). In 2012, there were 110 different Polish schools of all levels in Lithuania (Tab. 1), this being the only country beside Poland itself in which it is possible to study in Polish from the nursery through to higher education.

In the early 1990s the Social and Cultural Association of Poles in Lithuania sought to open a Polish university in Vilnius. This proved possible in 1991, with 150 students beginning their education at 4 Faculties in the first year. The available majors were: German Philology, English Philology, History, Pedagogy, Economics and Management, Law and Administration, Physical Education, Biology, Design and Information Technologies.

The problem with this concerned the University's failure to receive official registration. In this situation, and after many negotiations with the Lithuanian side in 1998, the University was registered by virtue of the law in force regarding public institutions, under the name of Universitas Studiorum Polona Vilnensis. This proved rather cold comfort, since no permission to award degrees was

Table 1. Number of educational institutions with Polish language of instruction in Lithuania in 2012

\begin{tabular}{|c|c|c|c|c|c|c|c|}
\hline \multirow[b]{2}{*}{ Administrative unit } & \multicolumn{6}{|c|}{ Type of school } & \multirow[b]{2}{*}{ Total } \\
\hline & $\begin{array}{l}\text { nursery } \\
\text { schools/ } \\
\text { kindergar- } \\
\text { tens }\end{array}$ & $\begin{array}{l}\text { primary } \\
\text { schools }\end{array}$ & $\begin{array}{l}\text { secondary } \\
\text { schools }\end{array}$ & $\begin{array}{l}\text { junior high } \\
\text { schools }\end{array}$ & $\begin{array}{l}\text { high } \\
\text { school }\end{array}$ & universities & \\
\hline Vilnius city & 3 & 0 & 6 & 2 & 7 & 3 & 21 \\
\hline Vilnius municipality & 20 & 7 & 19 & 3 & 16 & 0 & 65 \\
\hline Šalčininkai municipality & 3 & 0 & 8 & 2 & 6 & 0 & 19 \\
\hline Trakai municipality & 0 & 0 & 1 & 0 & 4 & 0 & 5 \\
\hline Švenčionys municipality & 0 & 0 & 1 & 1 & 0 & 0 & 2 \\
\hline Širvintos municipality & 0 & 0 & 1 & 0 & 0 & 0 & 1 \\
\hline Total & 26 & 7 & 36 & 8 & 33 & 3 & 110 \\
\hline
\end{tabular}

Source: based on www.wilnoteka.It, www.aikos.smm.lt, www.salcininkai.lt, www.vilniaus-r.lt, www.portalszkolny.org (as of 30 December 2012). 
granted. In consequence, after three years of study, students were sent to universities in Poland to complete their education (Bobryk 2006; Kurcz 2005).

SNPL also became the initiator of efforts to establish a branch of the University of Białystok in Vilnius in the academic year $2007 / 2008$. The greatest obstacle in this case concerned the need to amass appropriate funding, as well as the necessary documentation required by both Polish and Lithuanian institutions (Olędzki 2006). In May 2007, the University Research Centre for Quality of Studies did not extend permission for the branch to be set up, because the duration of undergraduate studies differed (3 years in Poland, 4 in Lithuania), the rank of the institution involved (the University of Białystok is not considered especially prestigious in Poland), the lack of a rationale for classes to be run in Polish, and the expected insufficient quality of education reflecting a lack of staff residing permanently in Vilnius (Olędzki \& Wołkonowski 2007). The creation of a branch of the University of Białystok in Vilnius nevertheless gained the support of many Polish organisations, including ZPL, AWPL or the Polish Educational Society (Macierz Szkolna). In June 2007, the Government of the Republic of Lithuania adopted a resolution authorising the establishment of the branch institution in question, whose students had a choice of economics or ICT courses (Grynia \& Wołkonowski 2008).

In 1990, numerous small-scale educational organisations were replaced by the Polish Educational Society (Bobryk 2006), the basic objectives of which are the creation of a system of Polish schools in Lithuania, the putting in place of appropriate conditions for young people to be taught in Polish schools, the raising of the level of education and the organisation of extra classes for talented young people (Masłowski 2005).

The leaders of Polish organisations emphasized that Poles in Lithuania set the best example for all Poles living away from the mother country. Uniquely in the world, these
Poles were able to turn to the co-governing country, have a minister, deputy ministers and government officials, and dominate or are part of the ruling majority in the local authorities in some districts. The main characteristics of Polish community in Lithuania are well-organised intuitional life and a need to unite.

\section{Institutional life of Lithuanians in Poland in 21st century}

The interests of the Lithuanian minority in Poland are currently (as of 2013) represented by seven non-governmental organisations, all of a national character. The objectives and activities of each organisation are very similar. Generally it can be said that the basic objective of all these societies is to maintain the Lithuanian national identity through the development of educational and cultural life. The main postulate is that state and local authorities should increase the funding assigned to Lithuanian education, and educational issues are indeed a priority for Lithuania's organisation. Lithuanian activists emphasize the very good relations with the authorities in Puńsk (which is perfectly understandable, since these are dominated by Lithuanians), countering this with what they deem to be the very bad relations in Sejny, where local authorities are unwilling to meet Lithuanian demands, especially for increased funding of Lithuanian schools. A 'policy of fait accompli' is also employed in relation to commemorations, monuments and the changing of street names. As their main achievements, Lithuanian activists refer to the continuation of cultural events despite difficulties with their financing, the protection of Lithuanian heritage in Suwałki region, activity as regards publishing, and the opening of the 'Žiburys' School with Lithuanian Language of Instruction in Sejny. Despite the relatively large number of Lithuanian organisations, their similar objectives and focus on a small area, there appears to be no rivalry, with working together happening seamlessly. The same cannot be said of other national minorities in Poland 

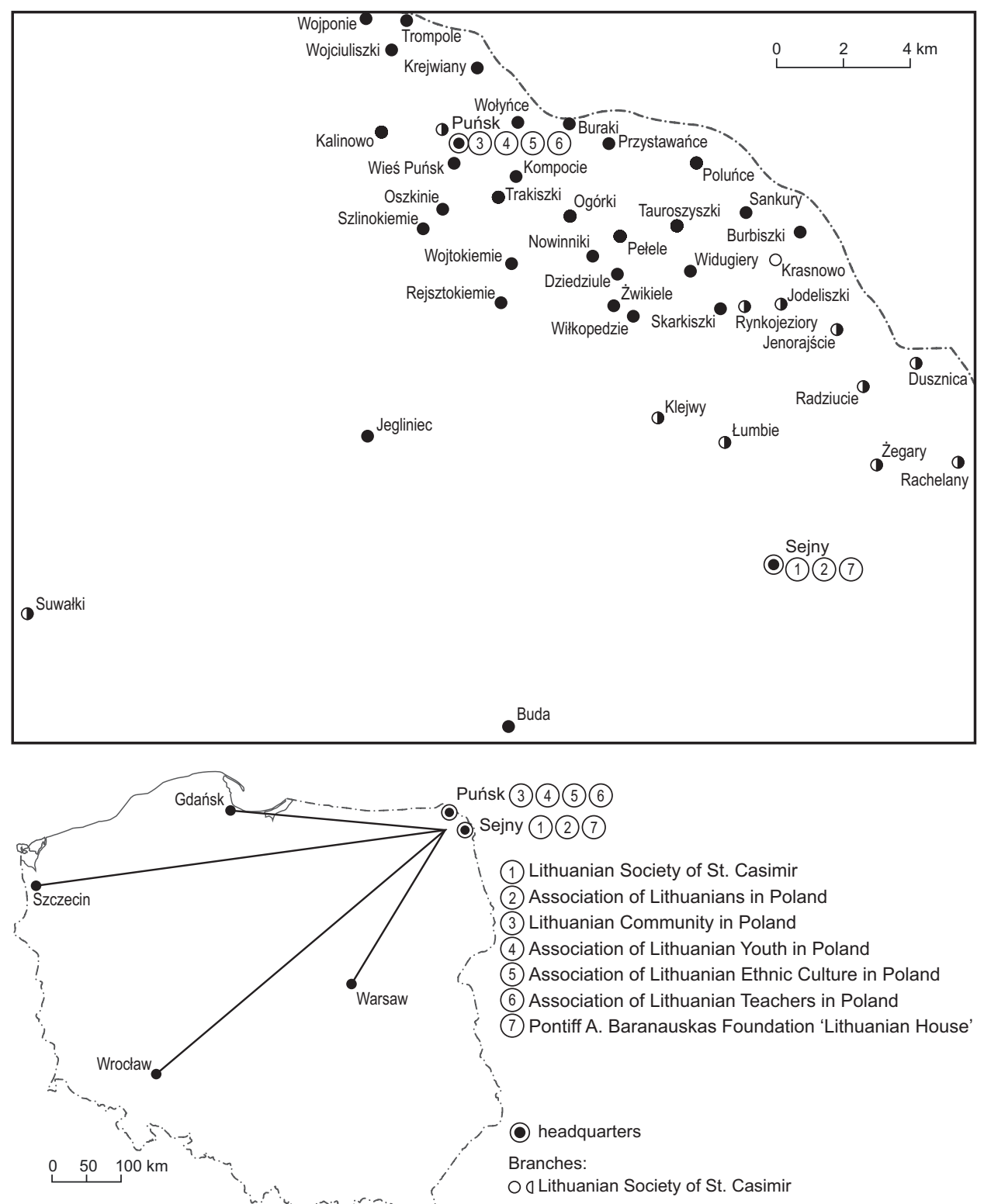

Figure 4. Location of Lithuanian organisations in Poland in 2012

and this fact significantly strengthens the relative position of Lithuanians there ${ }^{3}$.

\footnotetext{
3 Based on interviews conducted by the author in 2012 with activists of the Association of Lithuanians in Poland and the Lithuanian Society of St. Casimir.
}

The spatial structure characterising the Lithuanian organisations reflects the territorial concentration of Lithuanians in the north-eastern gminas of Puńsk and Sejny. It is in these two communities that the main offices of all the Lithuanian organisations 
are located. In addition, villages within these two gminas located close to the Polish-Lithuanian border play host to several branches of the Association of Lithuanians in Poland (Stowarzyszenie Litwinów w Polsce) and the Lithuanian Society of St. Casimir (Litewskie Towarzystwo Sw. Kazimierza), these being the only organisations with large-scale regional structures. However, unlike in the 1990s, most of the rural branches of the two organisations are either inactive or at best sporadically active, unlike the branches in Puńsk, Sejny and Suwałki (Barwiński 2009, 2013a).

One of the greatest achievements of the Lithuanian minority in Poland is well-organised education, which compares very favorably with education within other minorities in Poland, particularly as regards quality, and given the small size of the Lithuanian minority. In 2012, children and young people learnt the Lithuanian language in 13 schools - within the gminas of Puńsk and Sejny (Tab. 2), with 2 inter-branches in Suwałki. In most of these schools Lithuanian is the language of instruction, which means that all subjects are in Lithuanian (apart from lessons in the Polish language and Polish history and geography). The history and geography of Lithuania are taught in addition ${ }^{4}$. This model of teaching Lithuanians applies solely to the Lithuanian minority in Poland. The fact that there is teaching, not only of the Lithuanian language, but also in the Lithuanian language of most subjects at all levels of education, provides a basis for Lithuanian linguistic identity to be maintained, and is clearly also one of the main factors helping to maintain overall national identity. It is also possible to take exams in the Lithuanian language and in different subjects in Lithuanian, with further study of the Lithuanian language also being possible at the University of Poznań.

${ }^{4}$ While teaching in the Lithuanian language does take place in the case of mathematics, biology and chemistry, the textbooks for these subjects remain in Polish - a fact that simultaneously raises difficulties but also 'forces' bilingualism among children.
Nevertheless, the period since the mid1990s has brought gradual declines in both the number of students learning Lithuanian and the number of schools teaching that language (from a maximum of approximately 750-780 students in the years 1996-1999 to around 400-500 students now). This is less a consequence of any decline in interest in learning and more a reflection of wider demographic trends affecting all types of school. Teaching in the mother tongue still therefore extends to around $70 \%$ of the Lithuanian-minority children of school age. This is the achievement of parents, teachers and Lithuanian organisations, as well as a reflection of the financial assistance conferred upon the Lithuanian authorities, and the ongoing territorial concentration of Lithuanians. The well-organised, stable and universal system of Lithuanian education represents one of the main - if not the main - reasons for what remains only a slight degree of assimilation of the Lithuanians living in the Suwałki Region (Barwiński 2013a).

While limiting the rights of national minorities on their territory, the Lithuanian authorities have at the same time extended support of a financial, organisational and political nature to ethnic Lithuanians living abroad, including in Poland. This commitment is inter alia expressed in major expenditure on minority activity. For example, the Lithuanian government funded the construction of the 'Lithuanian House' in Sejny (which houses, among other things, the Consulate of the Republic of Lithuania, the boards of Lithuanian associations, bands, choirs and folk groups), as well as the building of the 'Žiburys' School Complex with Lithuanianlanguage instruction. In Puńsk, the Lithuanian government co-financed and provided for the construction of the 'House of Lithuanian Culture'. It also subsidizes schools, the operation of Lithuanian minority organisations and the 'Aušra' publishing house. The President of the Association of Lithuanians in Poland likewise emphasizes the significance of multi-faceted support extended by such Lithuanian authorities and institutions as the Ministry of Foreign 
Table 2. Lithuanian education in Poland in the school year 2011/2012

\begin{tabular}{|c|c|c|}
\hline \multirow{2}{*}{ Type } & \multicolumn{2}{|c|}{ Schools } \\
\hline & with Lithuanian teaching language & $\begin{array}{l}\text { with additional teaching } \\
\text { of the Lithuanian language }\end{array}$ \\
\hline Primary school & $\begin{array}{l}\text { Puńsk } \\
\text { Sejny (non-public) } \\
\text { Widugiery (gmina of Puńsk) } \\
\text { Przystawańce (gmina of Puńsk) } \\
\text { Nowiniki (gmina of Puńsk) }\end{array}$ & $\begin{array}{l}\text { Sejny } \\
\text { Krasnowo (gmina of Puńsk) }\end{array}$ \\
\hline Junior high school & $\begin{array}{l}\text { Puńsk } \\
\text { Sejny (non-public) }\end{array}$ & Sejny (2 junior high schools) \\
\hline High school & Puńsk & Sejny \\
\hline Total (13) & 8 & 5 \\
\hline
\end{tabular}

Affairs, the Ministry of Education, the Institute of Lithuanian Language and Lithuanian schools. At the same time, Lithuanian activists agree that Polish-Lithuanian relations have a very negative impact on the situation regarding Lithuanian and Polish perceptions, as well as on the reception of and opinions on Lithuanians held by Poles in the Polish-Lithuanian borderland. According to them, the Lithuanian minority is a "a hostage of the foreign-policy situation between Poland and Lithuania", and any deterioration in relations between Warsaw and Vilnius has a bearing on the situation in Puńsk and Sejny. This relationship is considered to be very unfavourable, unjust, or even dangerous, and there is thought to be a direct relationship between the political situation in Lithuania and the painting-over of bilingual town names that took place across the gmina of Puńsk in August 2011. In the view of Lithuanians, this was an act inspired from outside (Barwiński 2013a, b).

Lithuanians in Poland do, however, assess very positively the consequences for themselves of both Poland and Lithuania having joined the EU. A right especially prized involved free crossing of the border between the countries - surely a matter of fundamental importance for people living for decades in a borderland in the immediate vicinity of their kin-state. This is particularly important given that the geographical proximity in question did not entail freedom of mutual contacts even before the communist era indeed practically from the beginning of the 1920s. For dozens of years, therefore, the Polish-Lithuanian border was a very tight barrier that prevented, not only normal cross-border cooperation, but even visits between family members living a few or a dozen kilometres apart. No surprise then that the most important aspect of European integration for the Lithuanians living in Poland is the literal and practical integration of the Polish-Lithuanian borderland area $^{5}$.

\section{Conclusions}

The work described in this paper has focused on analyzing the situation of the Polish minority in Lithuania and the Lithuanian minority in Poland, from the institutional point of view.

Despite the many sensitive issues shaping relations between the Lithuanian state and the Polish minority, Polish organisations and institutions have freedom to operate and a real opportunity to influence local Polish communities. In the Vilnius and Šalčininkai regions, a large part of the local administration is dominated by the Polish minority, there are representatives of Electoral Action of Poles in the Lithuanian Parliament, Polish schools are in operation (if with numerous

\footnotetext{
${ }^{5}$ Based on interviews with activists of the Lithuanian Association in Poland and Lithuanian Society of St. Casimir.
} 
problems), and education also operates at university level.

After both Poland and Lithuania joined the EU, and the tendency for administrative and economic barriers between the two countries to be removed became more prominent and as the Lithuanisation of Vilnius progressed even the Lithuanian circles resentful of the Polish minority seemed to realise that the latter does not pose any threat to the territorial integrity of the Lithuanian state.

However, the lack of support for Polish territorial autonomy, the issues surrounding the acceptance of demands on the spelling of Polish names or bilingual signs, and the provisions included in new law on education all show that Lithuanians remain afraid of Polish separatism, and treat many initiatives launched by the Polish minority as acts against Lithuanian sovereignty (Kowalski 2008).

The resolution of bilateral problems is surely hindered, not only by the lack of goodwill, but also by the disproportionate nationality structure characterising the two countries. Lithuanians in Poland are a marginal nationality, both in numbers and territory inhabited. Tight groups of Lithuanians live in the north-eastern corner of Poland, along the border with Lithuania (Fig. 4), but even here a majority is only achieved in the gmina of Puńsk. According to the 2011 census, there are no more than some 8000 ethnic Lithuanians and people of Lithuanian origin living in Poland.

In contrast, the Poles in Lithuania constitute the largest ethnic minority there (some 200,000 out of 3 million people), and their olden-day (and even 20th-century) ancestors and fellow countrymen and women were significant shapers of the history of Lithuania. What is more, there are a large number of ethnic Poles living in the very capital of Lithuania - Vilnius, and they are able to dominate in both numerical terms and as regards political influence around the Lithuanian capital.

Of course, these objective differences do not excuse or justify the asymmetry in the

Table 3. Comparison of the contemporary situation of Poles in Lithuania and Lithuanians in Poland

\begin{tabular}{|l|c|c|}
\hline \multicolumn{1}{|c|}{ Criteria } & Poles in Lithuania & Lithuanians in Poland \\
\hline Nature of presence & indigenous & indigenous \\
Origin of distribution & boundary changes & boundary changes \\
Type of distribution & compact & compact \\
Statutory protection of minorities & no & yes \\
Minority language as an auxiliary language & no \\
Bilingual naming of towns, villages and streets & illegal & legal \\
Financial support for schools of national minorities & $115 \%$ & yes \\
Spelling of names with original diacritical marks & no & very small \\
Relative size of group & large & very good, intensive \\
Relationship with the homeland & very high \\
Extent of institutional integration & very high & very high \\
National distinctiveness & very high & Lacking \\
Religious distinctiveness & lacking & very high \\
Linguistic distinctiveness & very high & very good \\
Organisation of mother-tongue teaching & very good & very low \\
Susceptibility to assimilation & very low & very low \\
Participation in political and social life & very high & neutral \\
Relationship with the nation-state & negative & positive \\
Relationship with other national minorities & positive & neutral \\
Relationship between main nation and minority & negative & negative \\
Relationship between local authorities and minority & negative & \\
\hline
\end{tabular}


relationship towards the respective minorities characterising the two countries. First and foremost, the Government of the Republic of Lithuania, regardless of changing political options, has consistently failed to comply fully with the provisions of the Treaty of 1994 concluded with Poland, to the extent that discrimination against Poles can be regarded as taking place.

A comparison of contemporary ethnic structure and national policy in Poland and Lithuania makes clear the asymmetry in both its quantitative and legal-institutional aspects. There is currently a markedly smaller population of members of the Lithuanian minority living in Poland than of ethnic Poles residing on Lithuanian territory. At the same time, the national minorities in Poland enjoy fuller rights and better conditions for activity than do Poles living in Lithuania.

In discussing interstate relations where national minorities are concerned, the 'rule of reciprocity' in bilateral relations is often invoked. The discussion on this, but also the actions on the two sides, very often envisage a struggle between, as Nijakowski (2000) put it, the 'Old Testament' version, which

\section{References}

BarWIŃski M., 2009. Mniejszość litewska na tle przemian politycznych Polski po Il wojnie światowej. [in:] M. Kulesza (ed.), Geografia historyczna jako determinanta rozwoju nauk humanistycznych, Legnica-Łódź: Państwowa Wyższa Szkoła Zawodowa im. Witelona, Katedra Geografii Politycznej i Studiów Regionalnych, Uniwersytet Łódzki, pp. 121-136.

BARWIŃSKI M., 2010. Changes in the social, political and legal situation of national and ethnic minorities in Poland after 1990. [in:] J. Kitowski (ed.), 20 years of socio-economic transformations in countries of Central and Eastern Europe: An attempt of accounts, Geopolitical Studies, vol. 16, Warszawa: Instytut Geografii i Przestrzennego Zagospodarowania PAN, pp. 223-244. demands that you give rights to a given minority according to the rule that: we will treat 'your people' as badly (give them as few rights) as is justified by the way 'our people' are treated by you; and the 'New Testament' version, which applies the rule of: "look how good your people have it with us". One has to hope that the latter version will become more and more prominent. As Nijakowski says when discussing the relations between Poland and the foreign kin-states with 'Polish' minorities, it is this version that should be the model, while the former attitude should be seen for what it is - neither ethically admissible, nor politically beneficial.

\section{Acknowledgments}

Article written as part of research sponsored by the National Science Centre on the basis of decision no. DEC-2011/01/B/HS4/02609 and DEC-2011/01/N/HS4/02144.

\section{Editors' note:}

Unless otherwise stated, the sources of tables and figures are the author(s), on the basis of their own research.

BARWIŃSKI M., 2013a. Geograficzno-polityczne uwarunkowania sytuacji Ukraińców, Łemków, Białorusinów i Litwinów w Polsce po 1944 roku. Łódź: Wydawnictwo Uniwersytetu Łódzkiego, $348 \mathrm{pp}$.

BARWIŃSKI M., 2013b. Polish interstate relations with Ukraine, Belarus and Lithuania after 1990 in the context of the situation of national minorities. European Spatial Research and Policy, vol. 20, no. 1, pp. 5-26.

BIAŁEK T., 2008. Międzynarodowe standardy ochrony praw mniejszości narodowych i ich realizacja na przykładzie Białorusi, Litwy i Ukrainy. Warszawa: Wydawnictwo Naukowe Scholar, 322 pp.

BOBRYK A., 2006. Odrodzenie narodowe Polaków w Republice Litewskiej 1987-1997. Toruń: Dom Wydawniczy Duet, 554 pp. 
BRODOWSKI L., 2000. Lituanizacja kultury polskiej. [in:] J. Wyrozumski (ed.), Kultura Litwy i Polski w dziejach. Tożsamość i współistnienie. Materiały międzynarodowej konferencji zorganizowanej w dniach 15-17 października 1998, Kraków: Międzynarodowe Centrum Kultury, 204 pp.

BudYTA-BuDZYŃSKA M., 2010. Socjologia narodu i konfliktów etnicznych. Warszawa: Wydawnictwo Naukowe PWN, 316 pp.

DzIENNIK USTAW, 1997. Konstytucja Rzeczypospolitej Polskiej z dnia 2 kwietnia 1997 r., Dziennik Ustaw, no. 78, item 483, Warszawa: Sejm Rzeczypospolitej Polskiej, 58 pp.

DzienNik UstaW, 2005. Ustawa z dnia 6 stycznia 2005 r. o mniejszościach narodowych i etnicznych oraz o języku regionalnym. Dziennik Ustaw, no. 17, item 141, Warszawa: Sejm Rzeczypospolitej Polskiej, 9 pp.

Eberhardt P., 1996. Między Rosja a Niemcami. Przemiany narodowościowe w Europie Środkowo-Wschodniej w XX w. Warszawa: Wydawnictwo Naukowe PWN, 426 pp.

Eberhardt P., 1997. Przemiany narodowościowe na Litwie. Warszawa: Przegląd Wschodni, $307 \mathrm{pp}$.

Eberhardt P., 2009. Przemiany narodowościowe w państwach bałtyckich na przełomie XX i XXI wieku. [in:] Roczniki Nauk Społecznych, vol. 1(37), pp. 95-113.

Godek A., 2005. Powstanie, program oraz działalność Akcji Wyborczej Polaków na Litwie. [in:] Z.J. Winnicki (ed.), Polska mniejszość narodowa w Europie Środkowo-Wschodniej. Nowe problemy i wyzwania wobec współczesnych przemian w państwach regionu, Wrocław: Oficyna Wydawnicza Arboretum, 258 pp.

GryniA A., WoŁKonowski J., 2007. Start Filii UwB w Wilnie. Nasz Uniwersytet, no. 4(11), Białystok: Uniwersytet w Białymstoku, 8-9 pp.

JACKIEWICZ M., 2007. Wileńska Encyklopedia 1939-2005. Warszawa: Ex Libris Galeria Polskiej Książki, 702 pp.

Janusz G., 2011. Ochrona praw mniejszości narodowych w Europie. Lublin: Wydawnictwo Uniwersytetu Marii Curie-Skłodowskiej, 764 pp.

KowalSKI M., 2008. Wileńszczyzna jako problem geopolityczny wXX wieku. [in:] P. Eberhardt(ed.), Problematyka geopolityczna ziem polskich, Prace Geograficzne, no. 218, Warszawa: Instytut
Geografii i Przestrzennego Zagospodarowania PAN, pp. 267-298.

KURCzZ., 2005. Mniejszość polska na Wileńszczyźnie - Studium socjologiczne. Acta Universitatis Wratislaviensis, no. 2764, Wrocław: Wydawnictwo Uniwersytetu Wrocławskiego, 467 pp.

KUZBORSKA E., 2012. Sytuacja prawna mniejszości narodowych na Litwie. Warszawa: Wydawnictwo Sejmowe. Kancelaria Sejmu, 311 pp.

LEŚNIEWSKA K., 2009. Polska mniejszość we wspótczesnym Wilnie w kontekście polsko-litewskich stosunków międzynarodowych. [MA thesis written in the Department of Political Geography and Regional Studies in University of Łódź under the supervision of M. Barwiński].

LEŚNIEWSKA K., 2013. The socio-political situation of Poles in Vilnius after the accession of Lithuania to the European Union. [in:] K. Heffner (ed.), The eastern dimension of the United Europe - Political and economical aspects of the Eastern politics of the European Union, Region and Regionalism, vol. 2, no. 11, Łódź-Opole: University of Łódź. Department of Political Geography and Regional Studies, Governmental Research Institute, Silesian Institute, pp. 41-53.

LISIEWICZ J., 2013. Wyrok zapadt. Co dalej? Zwiqzek Polaków na Litwie, http://www.zpl.lt/replika/wyrok-zapadl-co-dalej/ [24 January 2014].

ŁODZIŃSKI S., 1998. Ochrona praw osób należacych do mniejszości narodowych i etnicznych (Ukraina, Białoruś, Litwa, Łotwa). Warszawa: Kancelaria Sejmu. Biuro Studiów i Ekspertyz, 12 pp., http://biurose.sejm.gov.pl/teksty_pdf_98/i-598. pdf [24 January 2014].

MAsŁoWSKI P., 2005. Polskie organizacje na Litwie w latach 1989-1991. [in:] Z.J. Winnicki (ed.), Polska mniejszość narodowa w Europie Środkowo-Wschodniej. Nowe problemy i wyzwania wobec współczesnych przemian w państwach regionu, Wrocław: Oficyna Wydawnicza Arboretum, 258 pp.

Matulionis A., Beresnevičıūtė V., Leončikas T.,

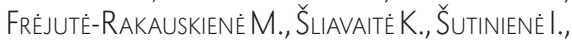
Žilinskaité V., Heinrich H.-G., Alekseeva O., 2011. The Polish minority in Lithuania. ENRIEast Project, Research Report, no. 8, 110 pp., http://www.enri-east.net/wp-content/uploads/ pl\%28LT\%29_FINAL_Feb3_09022012.pdf [23 January 2014].

Mole R.C.M., 2012. The Baltic States from the Soviet Union to the European Union: Identity, discourse and power in the post-communist 
transition of Estonia, Latvia and Lithuania. New York: Routledge, 196 pp.

NIJAKOWSKI L., 2000. "Pomosty” i „zasieki”, czyli o drogach pojednania. Mniejszości narodowe i etniczne a polska polityka wschodnia. Rubikon, no. 4(11), Warszawa: Klub Dyskusyjny Kartoteka, pp. 19-33.

Olędzkı P., WoŁkOnOwski J., 2007. Filia w Wilnie - bieg z przeszkodami. Nasz Uniwersytet, no. 3(10), Białystok: Uniwersytet w Białymstoku, pp. 6-8.

Osıpowicz C., 2001. Szkolnictwo polskiej mniejszości narodowej na Litwie. http://wspolnotapolska.org.pl/imprezy/impreza/Zjazdy-Polonii-i-Polakow-z-Zagranicy, 50.html [24 January 2014].

Rzemieniewski D., SŁowIKowski B., 2001. Polacy na Litwie. Wybór dokumentów prawnych dotyczacych mniejszości narodowych. Vol. 3, Warszawa: Stowarzyszenie Wspólnota Polska, $132 \mathrm{pp}$.
TRUsewicz E., 2005. Zmienna sytuacja prawna Polaków na Litwie. [in:] Z.J. Winnicki (ed.), Polska mniejszość narodowa w Europie Środkowo-Wschodniej. Nowe problemy i wyzwania wobec współczesnych przemian w państwach regionu, Wrocław: Oficyna Wydawnicza Arboretum, $258 \mathrm{pp}$.

WotŁEJKo M., 2011. Sytuacja mniejszości polskiej na Litwie a relacje polsko-litewskie. Bezpieczeństwo Narodowe, vol. 17, no. 1, Warszawa: Biuro Bezpieczeństwa Narodowego, pp. 99-114.

ZAKRZEWSKI A.B. (introd.), WISNER H. (transl.), 2000. Konstytucja Republiki Litewskiej. Warszawa: Wydawnictwo Sejmowe, 89 pp.

ŻotęDOWSKI C., 2003. Białorusini i Litwini w Polsce, Polacy na Białorusi i Litwie. Uwarunkowania współczesnych stosunków między większościq i mniejszościami narodowymi. Warszawa: Oficyna Wydawnicza Aspra, 360 pp. 
http://rcin.org.pl 